\title{
A Perspective of Mimetic Literary Criticism in Charles Dickens' David Copperfield and Chinua Achebe's Things Fall Apart
}

\author{
Dr. Supriyatno.,Khasanuddin, MMPd.,Zainal Fanani, MM.,Ahmad Burhan, SPd. \\ SMK Negeri Kudu Jombang Jawa Timur Indonesia \\ E-mail: mizazuhadizavala@yahoo.com
}

\begin{abstract}
The research represents and reflects the life of human being in following, encouraging and fighting for how to reach the cultural identity in terms of rational and times for personal history, adventures, experience and sacrifice of life. Colored with the problems of social value, traditional norms, and dimensions of superiority-inferiority, the two narratives try to reveal the forms of paradoxical analyses and paradigm of structure of human life which is elaborated in the structures of plot in which imply on the cultural studies in a society to find out the self-identity. The analyses of the research are in the approach of mimetic criticism discussed as the reaction to the forms of imitation, reflection and representation and its colors, meanwhile the data analyzed in terms of qualitative method with the techniques of interpretative qualitative in the steps of data comprehensively read, interpretation of meaning and critical analyses.
\end{abstract}

Keywords: mimetic, imitation, reflection, representation

DOI: $10.7176 /$ JLLL/86-04

Publication date: February $28^{\text {th }} 2022$

\section{Introduction}

Literature is simply the list of book's that people think always be rewarding to the imagination. No people agree where that list starts and stops, since everyone's reading experience is different. It is a particular historical period of movement, which may often be cross-culture, it may be found in the literature of number of different cultures; for examples, Renaissance Literature, Romantic Literature, Surrealism Literature, Colonial Literature, the Literature of Independent Africa, and so on. In the broadest definition, the word of literature refers to anybody of written materials which have a lasting appeal and which is highly regarded and widely accepted by the readers. Usually this acceptance and regards are based on the expression of universal emotion or ideas in an attractive and appealing form. It is said a work of literature is a text that is valued by the culture which uses special language, and that effects people with emotions which are valued for their own benefit. Literature in daily life is quite familiar to human being. It is inseparable aspect of human's life and represents as it is regarded as the mirror of social life.

Literature is also the one form of man's expression needs the word to express the special idea, vision of life, and interest in human being life, and the poets' work offer the readers about kinds of the description of life, they may provide problems that must be faced by human beings. So the author needs to use a deep thinking in solving them, the solution of the problems. The authors can increase a new insight and a new experience for the readers, and a mirror of the real life, literature definitely contains thing happening in the life of human being and their surrounding, for literature creates its own world based on the real world.

Literature, is classified in two groups : (1) literature of knowledge or informative literature. It deals with facts, real people's life, and history. The function of this kind of literature is to present information to reach, and to offer knowledge, and example of informative literature : history books, philosophical works, scientific, articles, dictionaries, directories, instructional manuals, travel brochures, magazines, school text books, etc, (2) literature of power or imaginative literature, this deals with thoughts and feelings for examples : novels, poetry, short stories, plays, drama, etc.

Reading literature has many purposes, reading literature attentively and imaginatively promises further pleasure, the enjoyment of how the writer uses the language to create work of art, this way of reading brings us close to understand the achievement of the story and its writer. Reading literature is not merely aimed at giving an entertainment but it is also expected that the readers can use their intelligence in obtaining information in literature, beside that, literature adds the readers understanding of life in the world around them, and the readers can learn and find many aspects of life and characters because it is the reflection and representation of human life.

\section{The Review of Related Literature of Literary Criticism}

The general description of criticism dealing with the overall term for studies concerned with defining, classifying, analyzing, interpreting, and evaluating the works of literature. Theoretical criticism proposes a theory of literature, in the sense of general principles, together with a set of terms, distinction, and categories, to be applied to identifying and analyzing works of literature, as well as the criteria and the standards or norms by which these works and their writers are to be evaluated. Practical criticism, or applied criticism, concerns itself with the discussion of particular works and writers; in an applied critique, the theoretical principles controlling the mode 
of the analysis, interpretation, and evaluation are often left implicit, or brought in only as the occasion demands.

Impressionistic criticism attempt to represent in words the felt qualities of a particular passage or work, and to express the responses or the impression that the directly evokes from the critic. Judicial criticism, attempts not merely to communicate, but to analyze and explain the effects of a work by reference to its subject, organization, techniques, and style, and to base the critic's individual judgments on general standards of literary excellence. Mimetic criticism views the literary work as an imitation, or reflection, or representation of the world and human life, and the primary criterion applied to a work is that of the " truth ' of its representation of the world and human life. Expressive criticism treats a literary work as an expression, or overflow, or utterance of feelings, or as the product of the poet's or the writer's imagination operating on his or her perceptions, thoughts, and feelings; it tends to judge the work by its sincerity, or its adequacy to the poet's individual vision or state of mind; and it often looks in the work for evidences of the particular temperament and experiences of the author who, consciously or unconsciously, has revealed himself in it. Pragmatic criticism views the work as something which is constructed in order to achieve its aims due to the author's strategis and certain effect on the audience, and it tends to judge the value of the work according to its success in achieving that aim. This criticism is also dealing with the strategies of the author in creating the literary work, such as the ways in character or characterization, plot, conflict etc. Meanwhile, textual criticism aims to establish an accurate uncorrupted original text identical with what the author intended. This may involve collating manuscripts and printed versions, deciding on the validity of rediscovered versions or chapters, deciphering damaged manuscripts and illegible handwriting.

This article only limits to the mimetic criticism of David Copperfield and Things Fall Apart dealing with the author's creation in conducting the characters, characterizations, and main characters of the two narratives.

\section{Research Method}

This article is addressed to the qualitative research dealing with the study of social reality or with internal perspective. Qualitative research includes narrative research, phenomenology, grounded theory, ethnography, and case studies. Qualitative research is a situated activity that locates the observer in the world. It consists of a set of interpretive, material practices that make the world visible. These practices transform the world. They turn the world into a series of representations, including field notes, interviews, conversation, photographs, recordings, and memo to the self. At this level, qualitative research involves an interpretive, naturalistic approach. This means that qualitative researchers study things in natural setting, attempting to make sense of, or interpret, phenomena in terms of the meanings people bring to them (Creswell, 2007:35-36).

Several lists of characteristic of qualitative research are: 1) natural setting (field focused), a source of data for close interaction. Researchers collect data in the field where participants' experience the issue or problem under study; 2) researchers as key instrument of data collection; 3) multiple data sources in words or images; 4) analysis of data inductively, recursively, interactively; 5) focus on participants' perspective, their meanings, their subjective views; 6) framing of human behavior and belief within a social-political/historical context or through a cultural lens; 7) emergent rather than tightly prefigured design; 8) fundamentally interpretive inquiry --- researcher reflects on her or on his role, the role of the reader, and the role of the participants in shaping the study, holistic view of social phenomena (Creswell, 2007:38).

The study of the qualitative research refers to the meanings, concepts, definitions, characteristics, metaphors, symbols, and descriptions of things (Berg, 2001:3). It also goes to five features of qualitative research covering studying the meaning of people's lives, under real-world, representing the views and perspectives of the people in a study, covering the contextual conditions within people live, contributing insights into existing or emerging concepts that may help to explain human social behavior and striving to use multiple sources of evidence rather than relying on a single source alone (Yin, 2011:8).

The philosophical underpinnings of qualitative research approach direct to several key features that characterize this research. One of them is an exploratory and descriptive focus. It emphasizes that qualitative research is designed to discover what can be learned about some phenomenon of interest, particularly social phenomena where people are the participant, or as traditionally referred to subjects of the research (Maykut, 1994:39). It develops a general focus of inquiry that helps to guide the discovery of what is to be known about some social phenomenon. Researcher investigates and responds to exploratory and descriptive question. For qualitative researchers, the lived experiences of real people in real setting are natural setting or the objects of study. Understanding how individuals make sense of everyday lives is the stuff of this inquiry. In qualitative work, the intent is to explore human behavior within the contexts of the natural occurrence. It seeks to understand the world from the perspectives of those living in. It is axiomatic in this view that individuals act on the world based not on some supposed objective reality but on the perception of the realities that surround them. Qualitative studies try to capture the perspective that actors use as a basis for their actions in specific social settings (Hatch, 2002:6-7). 


\section{Discussion and Result}

\subsection{The Mimetic Criticism in Charles Dickens' David Copperfield}

The mimetic criticism of the literary works relate to the essences and natures of the imitation, reflection, and representation of human life and emotion. The literary works are in the forms of fictions, but the fictions are the reflection of human life or particularly, human emotion which are depicted in the plot of the story of the two narratives, drama, or poems. It can be seen the phenomenon which happen in the community life. But sometimes this cannot be considered for the whole. Through the literary works having the phenomenon can be expressed, or can be represented. The society life cannot get rid of what it is called of virtue and vice because these are the characterizations of human being. Virtue and vice color the aspects of human life. It depends on what they do or they make. The community, therefore, can read and comprehend the virtue and vice through the literary works as the moral teaching, norms and the range of the contemplation for life in the future.

In Charles Dicken's David Copperfield, he attempts to reflect one side of human life which is characterized and told by almost entirely from the point of view and dimensions of the first person narrator, David Copperfield. He has been the main character of the novel. He plays the role as a man in this novel, according to the general outlook of the mimetic criticism, i.e., imitation of human life, the reflection of human life, and the representation of human emotion, the plot of this novel tends to the sheer imitation means that the novel describes us a sequence of the story dealing with the personal history, adventures of life, experience and observation of David Copperfield, and many elements within the novel follow the range of events in Dicken's own life, and this is also involving his autobiography. David Copperfield is the imitation of his own life, how to fight for and struggle for life, how to survive for living, how to solve many problems and challenging in life. This is clear that the first person point of view is reflected by the writer of the novel. The imitation and reflection of life is much conveyed in it, such as, how he has to live with his stepfather, how to work hard in a factory in London, how to feel the experience of life when his family, encompassing his mother and baby die. All are expressed in this narrative as the imitation and reflection of human life aimed at the readers that life is reflection before men do everything or after men have done everything. In the representation of human emotion, how David Copperfield can feel against many problems and challenging in his life, what he feels the life conflicts, how nobody cares for him in London until he escapes, walks all the way from London to Dover, and survives for living. The elements of the narration of the novel do not only emphasize on the struggle, distress, sacrifice, and fighting for living, but the representation of his love as well when David Copperfield has been in the soul-searching and then finds the true happiness as well as marries Agnes Wickfield who is sensible and in love with him.

\subsection{The Mimetic Criticism in Chinua Achebe's Things Fall Apart}

In relations between the other cultures, belief involved in the sphere of the superiority or inferiority, due to restricted and partial worldview are sometimes considered as everything destructive and wrong-headed. When the new cultures and religion meet, there is likely to be the fight and the struggle for dominance. For example, the Christians and Okonkwo's people have a limited view of each other, and have very difficult time understanding and receiving the other's customs and belief, implying the violence as with the destruction of the local church and the murder of Okonkwo's messenger. In spite of the opportunities for the comprehension, people must strive to have the communication. For example, Okonkwo and his son, Nwoye has the difficult time for the understanding to each other because they hold the different values and attitude. On the one hand, Okonkwo has spent much more time with Ikemefuna and developed the more profound relationship which seems to go beyond the cultural challenging and restraints.

The social value - such as the individual ideal and ambition - that is constructive thing when it is balanced by the other values to be destructive as well as that is overemphasized at the expense of the other values of the sequence of life. Such as, the presence of the Okonkwo value tradition is so wide that he cannot receive the changing. This can be more accurate to reveal the values of the tradition because this is the high cost he has had paid to uphold it, i.e., murdering Ikemefuna and moving to Mbanta. The Christian religious teachings render these large struggles and sacrifices on his meaningful parts of life. The great distress of the loss of tradition, whether this is really driven by his love of

the tradition or the meaning of his struggle and sacrifices, it can be seen as the main reasons for his suicide. There is no such thing as the static culture; change has been the continual thing, and the flexibility is necessary for the successful adaptation because Okonkwo cannot receive the changes of Christian religious teachings and he cannot have the adaption. The struggle and sacrifice between change and tradition is constant, however, this only appears to and happens to Okonkwo. The change can be well accepted, as evidenced by how the people of Umuofia rejected to have the relations to Okonkwo as he struck down the white man at the last thing. It was possible he was not so much bothered by change, but the opinions and the ideas of losing everything he has built up and a lot thought - his luck, fame, title, etc., which would be replaced by new customs. The suicide can be considered as the final attempt and struggle to denote to many people of Umuofia the effects of the clash between the existence of cultures and as a tool for the Igbo society, civilization, and culture to be upheld and developed. 
In mimetic literary criticism, the presence and the roles of Okonkwo take the very important attitude in community life, within the aspects of the imitation, reflection, or representation of his life. The life that encompasses the acts of the elements of the virtue or the vice, the existence of success or the failure in life or the roles for his society. The notion of failure relates to the ideas or thinking of change in Umuofia as well as the dimensions of shift in cultural values and the point of view of civilizations. Failure, for Okonkwo, is the community interaction reform, and the individuals provide strength from the community, and societies derive strength from the individual life who belongs to them. In Things Fall Apart, Okonkwo creates his luck and fortune and strength with the roles and help of the community's traditions and customs. Okonkwo's community's benefits from their hard work as well as determination.

\section{The Synopsis of the Novel}

\section{a. The Synopsis of Charles Dickens' David Copperfield}

The story of the novel relates to the life of David Copperfield since he has been a child up to the times of maturity. He was born in England in 1820. His father died six months before he was born. Seven years later, his mother marries Mr. Edward Murdstone. David has been provided good reasons to dislike his stepfather. Mr. Murdstone gains the thrashings David for falling behind with the studies. Following one of these thrashings, David has biten him and has been sent away to a boarding school, Salem House, with the ruthless headmaster. His name is Mr. Creakle. Here he befriends James Steerforth and Tommy Traddles, both of whom he will meet again next.

David returns back home for the holidays to search for that his mother has had a baby boy. After that, he goes back to the Salem House, his mother and the baby die and he has to return back home as soon as possible. Mr. Murdstone sends him to have work in a factory in London, of which Murdstone has been the joint owner. His landlord, Mr. Wilkins Micawber, has been sent to the debtor's prison after going bankrupt, and there is for several months before being released and moving to Plymouth. David now is having nobody left to pay attention and to care for him in London as well as decides to escape. He gets walk all the way from the city of London to the city of Dover, only to meet his relative, his aunt Miss Betsey. Betsey Trotwood has agreed to bring him up, despite Mr. Murdstone visiting in a bid to regain custody of the presence of David. Betsey has renamed him Trotwood Copperfield, or shortened 'Trot".

The range of the story goes on David as he starts to grow to the adulthood, and has been enlivened by the many famous characters who enter, leave and re-enter the life. These can involve Peggotty, his faithful former housekeeper for his mother, the family, and the orphaned niece Little Emily who lives with them and makes charming for the young David. The specific characters get some measure of what they may deserve. Dan Peggotty safely transfers Little Em'ly to the new life in Australia; accompanying these two main characters are Mrs. Gummidge and the Micawbers. Everybody involved finally has found the security and happiness in their new life in Australia. David first marries his beautiful but this is naive Dora Spenlow, she dies after failing to recover from the early miscarriage in their marriage. Then, David can do some soul-searching and eventually gets married and finds the real happiness with the sensible and the elegant Agnes Wickfield, who had in silence always loved him very much. They have several children, including a daughter named in honour of Betsey Trotwood.

\subsection{The Synopsis of Chinua Achebe's Things Fall Apart}

Chinua Achebe's Things Fall Apart creates the exploration of the colonized Africa and one man's struggle to survive in a changing community. This plot of the novel begins with the protagonist Okonkwo, a wealthy and respected, honorable member of the Umuofia tribe. His elevated status has started in his times of youth when he defeats Amalinze the Cat in a wrestling match. The Okonkwo's father is a lazy irresponsible man. He hates his father and has done everything he can be nothing like him. As a young man, he begins and designs building his social status by defeating a great wrestler, driving him into good community's eye. He is one of the hard-workers and denotes no weakness - emotional or otherwise - to everyone. Although he is considered to be coarse with the family and neighbours, on the contrary, he is wealthy, courageous, and powerful among the people of his village and society. He is the leader of his village and his place in that community is what he has striven for the whole life. So, Okonkwo has been selected by the elders to be the guardian of Ikemefuna, a boy taken prisoner by the village as the peace settlement between two villages after his father does the murder to Umuofian woman. Ikemefuna stays with Okonkwo up to the Oracle provides the instructions for the elders on what to undertake with the boy. For three years, the boy lives with the Okonkwo's family and he can grow fond of him, even he considers Okonkwo his father. Later on, the elders can decide that the boy has to be killed, as well as the oldest man in the village gives warning for Okonkwo to have nothing to do with the case of the murder because this will be like the act of killing his own child. Rather than this seems weak and feminine condition to the other men of the village and society, Okonkwo helps to kill the boy in spite of the warning of the old man. In fact, Okonkwo himself strikes the murdering blow as Ikemefuna has begged him for the protection. Shortly after Ikemefuna's death, the things start to go wrong for Okonkwo. While he accidently murders someone at the ritual funeral ceremony when his gun explodes, he and his family have been sent into the exile for seven years to appease the gods he has offended with 
the act of murdering. When Okonkwo has been away in exile, white men start coming to Umuofia and they peacefully provide the introduction of their religion. As the number of converts increases and develops, the foothold of the white people grows and also develops beyond the religion and the new government is introduced.

Okonkwo returns back to his village after his exile to find it the changed place because of the presence and the roles of the white men. He and other tribal leaders attempt to reclaim the holding on their native land by destroying the local Christian church which has insulted and undertaken defamation to their gods and religious teachings. In return, the leader of the white government takes them to be the prisoners and holds them for ransom for a short while, further humiliating and insulting the native leaders. It implies for the people of Umuofia finally gather for what can be the great uprising. Okonkwo insists on and is adamant over following native and traditional Umuofian custom and tradition, despises any form of cowardice and advocates for war against the group of white men. While messengers of the white government attempt to stop the meeting, Okonkwo has killed one of them. He has realized with despair that the people of Umuofia are not going to fight to protect themselves because they let the other messengers escape and so all is lost for the village. When the local leader of the white government comes to Okonkwo's house to take him to court, he finds that Okonkwo has hanged himself, ruining his great reputation as it is strictly against the customs of the Ibo to undertake the killing oneself.

\section{VI.Conclusion}

Mimetic literary criticism is one of the literary criticisms dealing with the dimensions of the imitation, reflection, and representation of human life and human emotion. In these two narratives, the natures and the essences of the mimetic literary criticism have been written. These are reflected and represented in the main characters of the narratives which take their roles in imitating, reflecting and representing human life and human emotion. Eventhough these are the fictions as the literary works but these can be the moral teachings or values in societal life.

Referring to the finding of the research in the article is how human struggling for the survival of living, no sense of weakness to gain idealism of life and to elevate human social stratification.

\section{Acknowledgements}

We would like to express our deep gratitude to Pemerintah Provinsi Jawa Timur, Dinas Pendidikan Provinsi Jawa Timur, BPSDM Provinsi Jawa Timur, Cabang Dinas Pendidikan Provinsi Jawa Timur Wilayah Kabupaten Jombang, SMK Negeri Kudu Jombang which facilitated to conduct the research, and also goes to IISTE which accepted and published the article.

\section{BIBLIOGRAPHY}

Abrams, M.H. 1993. A Glossary of Literary Term, Sixth Edition, New York: Holt, Rhinerhart and Winston Inc. Achebe, Chinua. 1995. Things Fall Apart. Knopf Doubled Publishing Group.

Berg, Bruce L. 2001. Qualitative Research Methods For the Social Sciences. Fourth Edition. A Pearson Education Company. 160 Gould Street Needham Heights, MA 02494.

Creswell, John W. 2007. Qualitative Inquiry and Research Design. Choosing Among Five Approaches. Second Edition. California: Sage Publication, Inc. 2455 Teller Road, Thousand Oaks, California 91320.

Dickens, Charles. 1977. David Copperfield. Oxford University Press.

Guerin, Wiefred L. 1999. A Handbook of Critical Approaches to Literature. Oxford. Oxford University Press.

Hatch, J. Amos. 2002. Doing Qualitative Research in Education Settings. New York. State University of New York Press, Albany.

Jones, Edward H. 1988. Outlines of Literature. Macmillan Company. New York.

Kooistra., J and J.H. Schut. 1964. A Shorter Introduction to English Literature. J.B. Wolters - Groningen Batavia. Maykut, Pamela and Richard Morehouse. 1994. Beginning Qualitative Research, Philosophic, and Practical Guide. London: UK, The Falmer Press, 4 John Street, London WCIN 2 ET.

Yin, Robert K. 2011. Qualitative Research from Start to Finish. New York: The Guildford Press. A Division of Guildford Publication, Inc. 72 Spring Street. New York, NY 10012. 